\title{
Pharmacognostic Studies and HPLC Analysis of Roots of Helicteres isora (L.)
}

\author{
Pinal A. Harde ${ }^{1 *}$ and Mamta B. Shah ${ }^{2}$
}

Pinal A. Harde ${ }^{1 *}$ and Mamta B. Shah ${ }^{2}$

'Department of Pharmacognosy, C.K. Pithawalla Institute of Pharmaceutical Science and Research, Surat, Gujarat, INDIA.

${ }^{2}$ Department of Pharmacognosy, L. M. College of Pharmacy, Ahmedabad, Gujarat, INDIA.

\section{Correspondence}

Dr. Pinal A. Harde, Department of Pharmacognosy, C.K. Pithawalla Institute of Pharmaceutical Science and Research,Surat. Gujarat, INDIA.

Phone number: 9904050524

E-mail: pinalharde@gmail.com

\section{History}

- Submission Date: 03-12-2016:

- Review completed: 21-01-2017;

- Accepted Date: 13-03-2017.

\section{DOI : 10.5530/pj.2017.4.84}

Article Available online http://www.phcogj.com/v9/i4

\section{Copyright}

(C) 2017 Phcog.Net. This is an openaccess article distributed under the terms of the Creative Commons Attribution 4.0 International license.

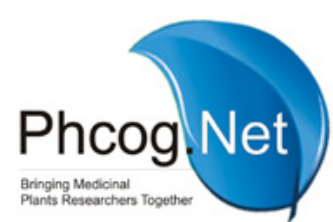

\begin{abstract}
Background: The juice of roots of Helicteres isora Linn. has been widely used as an antidiabetic in traditional medicine. Objective: The present study deals with pharmacognostical studies and determination of oleanolic acid from the roots of $\mathrm{H}$. isora by new HPLC method. Materials and methods: Detailed study of morphological, microscopical characteristics, physicochemical parameters and phytochemical screening of roots were carried out. The sapogenins were isolated from the roots of $H$. isora. RP-HPLC method was developed and validated for estimation of oleanolic acid from the sapogenins of roots of $H$. isora. Results: Detailed quality control parameters of roots of $H$. isora were reported. Total content of oleanolic acid was $0.075 \% \mathrm{w} / \mathrm{w}$ from roots of $\mathrm{H}$. isora determined by HPLC. Conclusion: The present study is useful for accurate identification and authentication of roots of $H$. isora. The HPLC method for determination of oleanolic acid from the roots of $H$. isora is efficient, precise, reliable and sensitive and can be adopted for routine analysis.

Key words: HPLC, Oleanolic Acid, Sapogenins, Helicteres isora.
\end{abstract}

\section{INTRODUCTION}

Helicteres isora Linn. (Family: Streculiaceae) is a tall shrub or a small tree commonly known as 'Marophali' in Hindi and the 'East Indian Screw Tree' in English. It is found throughout Central and Western India, Ceylon and China. ${ }^{1-3}$ The capsule has long been employed in intestinal complaints, colic, flatulence and diarrhea in India. The juice of roots is used in diabetes, emphysema, stomach affections, scabies and snakebite. Roots are also used as expectorant, hepatoprotective, astringent to the bowels and anti galactogogue..$^{1-6}$ Triterpenoid glycosides namely, cucurbitacin B, isocucurbitacin B, oleanolic acid, daucosterol, isorin, $3 \beta$ 27diacetoxylup20(29)en-28-oic methyl ester catechol, gallic acid and betulic acid have been reported in roots. ${ }^{7-9}$ The triterpenoid saponins rich butanol extract of roots is shown to possess antihyperglycemic and antilipidemic activities in experimental animals. ${ }^{10-13}$ Oleanolic acid is stated to demonstrate antidiabetic, antilipidemic, cytotoxic, anti-ulcer, anti-inflammatory and antiprotozoal activities in animals. ${ }^{14-17}$ Thus, oleanolic acid (Figure 1) would be useful as a biological maker for qualitative assessment of roots of $H$. isora. ${ }^{18}$ Literature survey revealed that preliminary pharmacognostical studies and HPTLC method was developed and validated for analysis of oleanolic acid from the roots of H. isora. ${ }^{19,20}$ Further there is lack of literature with regard to detailed standardization of roots of $H$. isora. Thus the present study was steered towards pharmacognostic evaluation, and development of rapid and reproducible high-performance liquid chromatographic
(HPLC) method using oleanolic acid as a marker for qualitative assessment of roots of $H$. isora.

\section{MATERIALS AND METHODS}

\section{Plant material}

The fresh roots of Helicteres isora Linn. along with a twig were procured from Dhrampur, Gujarat, India in June-July. Authentication was done by Dr. Minoo Parabia, Ex. Botanist and Head of Bioscience Department, The Veer Narmad South Gujarat University, Surat. India (Voucher specimen no: $\mathrm{PAH} / 23082007 / 02)$. The roots were cut and dried properly, powdered to 60 -mesh. The powdered sample was stored in an air-tight container at room temperature $\left(28 \pm 2^{\circ} \mathrm{C}\right)$. Pharmacognostic evaluation including microscopy was carried out by taking free hand sectioning followed by staining with phloroglucinol and hydrochloric acid. Powder characteristics were also studied and photomicrographs were obtained by Magnus MLX-DX photomicroscope provided with Honestech software. Physicochemical constants like ash value, extractive value and phytochemical screening of roots were carried out. ${ }^{18-21}$

\section{HPLC analysis \\ Chemicals and Standard}

Petroleum ether $\left(60-80^{\circ} \mathrm{C}\right)$, ethyl acetate, $n$-butanol, methanol, diethyl ether (E. Merck, Mumbai, India) were of analytical grade. The solvents used for HPLC analysis, like methanol, orthophosphoric acid, water 
(Merck, Mumbai, India) were of HPLC grade. Standard oleanolic acid (purity $97 \%$ w/w) was purchased from Sigma-Aldrich Chemicals (Germany).

\section{Preparation of standard solution}

Standard stock solution of oleanolic acid $(0.2 \mathrm{mg} / \mathrm{ml})$ was prepared by dissolving an accurately weighed $10 \mathrm{mg}$ of pure powder of standard oleanolic acid in $50 \mathrm{ml}$ volumetric flask containing methanol and volume was adjusted with methanol up to the mark. Further 0.1, 0.2, 0.3, 0.4, 0.5, and $0.6 \mathrm{ml}$ of stock solution of oleanolic acid was transferred to $10 \mathrm{ml}$ volumetric flask separately and volume was adjusted with methanol up to the mark to produce working standard solutions of $2.0,4.0,6.0,8.0$, 10.0 and $12.0 \mu \mathrm{g} / \mathrm{ml}$.

\section{Isolation of saponins and sapogenins and preparation of sample} solution

An accurately weighed $(10 \mathrm{~g})$ root powder of $H$. isora was extracted successively with petroleum ether $\left(60-80^{\circ} \mathrm{C}\right)(3 \mathrm{X} 50 \mathrm{ml})$, ethyl acetate $(3 \mathrm{X} 50 \mathrm{ml})$ and $n$-butanol $(3 \mathrm{X} 50 \mathrm{ml})$ by hot maceration. The $n$-butanol extract was concentrated under vacuum to get semisolid residue that dissolved in $10 \mathrm{ml}$ of methanol and excess diethyl ether was added to yield bulky and sticky precipitates of saponins. The saponins were subjected to acid hydrolysis using $2 \mathrm{M} \mathrm{HCl}$ under reflux for $4 \mathrm{~h}$. The hydrosylate was extracted ethyl acetate $(3 \mathrm{X} 10 \mathrm{ml})$ and the pooled fraction on concentrating under reduced pressure yielded sapogenins. The later were dissolved in $8 \mathrm{ml}$ methanol in a $10 \mathrm{ml}$ volumetric flask and the volume was adjusted up to the mark with methanol. From this $1 \mathrm{ml}$ of sample solution was transferred to $10 \mathrm{ml}$ volumetric flask and the volume was adjusted up to the mark with methanol. The afforded solution was filtered through a $0.45 \mu \mathrm{m}$ syringe filter prior to application to HPLC.

\section{Chromatography}

A Shimadzu model of HPLC equipped with quaternary LC-2010 AHT VP pumps with variable wavelength programmable UV/VIS detector, SPD-10AVP column oven and Class-VP software were used. The chromatographic separations were performed using Phenomenex $\mathrm{C}_{18}$ (250 mm x $4.6 \mathrm{~mm}, 5 \mu \mathrm{m}$ particle size) column at $40{ }^{\circ} \mathrm{C}$ temperature. The optimized mobile phase was found to be methanol- $0.1 \%$ aqueous orthophosphoric acid 90:10 (\% $v / v)$. Auto sampler with injection volume $20 \mu \mathrm{l}$ was used and sample tray was kept at $15^{\circ} \mathrm{C}$ temperature. Analysis was done with flow rate of $0.6 \mathrm{ml} / \mathrm{min}$ at $210 \mathrm{~nm}$ wavelength using UV detector.

\section{HPLC Method Development and Validation}

The proposed RP-HPLC method was validated as per ICH guidelines. ${ }^{22}$

\section{Calibration Curve}

Graded concentrations of standard oleanolic acid solution 2.0, 4.0, 6.0, $8.0,10.0$ and $12.0 \mu \mathrm{g} / \mathrm{ml}$ of $20 \mu \mathrm{l}$ volume were injected serially by rheodyne injector in triplicates. Immediately, it was scanned at $\lambda_{\max } 210 \mathrm{~nm}$ by $\mathrm{UV} /$ visible detector. Data of peak area was recorded for each injection of standard solution. Standard calibration curve of mean peak area versus concentration of standard oleanolic acid was plotted. The calibration curve was analyzed through linear regression.

\section{Precision (Repeatability)}

The precision of the method was checked by repeatedly injecting $(n=6)$ standard solutions of oleanolic acid $(6.0 \mu \mathrm{g} / \mathrm{ml})$. The results were reported in terms of \% RSD.

\section{Intermediate precision (Reproducibility)}

Intermediate precision was evaluated in terms of intraday and interday precision. The intraday and interday precision of the proposed methods were determined by estimating the corresponding responses three times on the same day and on three consecutive days for three different concentrations $(4.0,6.0$ and $8.0 \mu \mathrm{g} / \mathrm{ml})$ of working standard solutions of oleanolic acid. The deviations in results were reported in terms of \% RSD.

\section{Accuracy (Recovery)}

The accuracy of the method was determined by calculating recoveries of oleanolic acid by the standard addition method. Known amounts of standard solutions of oleanolic acid (50, 100 and 150\%) were added to pre analyzed sample solution. Here, known amounts of standard solutions of oleanolic acid $(1.0,2.0$ and $3.0 \mu \mathrm{g} / \mathrm{ml})$ were spiked to prequantified sample solutions of roots of $H$. isora and analyzed by proposed method. The amount of oleanolic acid was estimated by applying these values to the regression equation of the calibration curve.

\section{Limit of detection and Limit of quantification}

The limit of detection (LOD) was determined by visually evaluating the minimum level at which the oleanolic acid could be reliably detected. The limit of quantification (LOQ) was determined by analyzing the known concentration of oleanolic acid at which it could be quantified with accepss accuracy and precision.

\section{Robustness}

Robustness study of the HPLC method was determined by applying small but deliberate changes in the flow rate, ratio of mobile phase, detection wavelength and column temperature and response of $6.0 \mu \mathrm{g} / \mathrm{ml}$ concentration of oleanolic acid was measured in terms of peak area and retention time. The results were expressed in terms of \% RSD.

\section{Quantification of oleanolic acid from roots of $\mathrm{H}$. isora}

The solutions of test sample was injected in triplicates and chromatograms were obtained under the same conditions as for analysis of standard oleanolic acid. The area of the peak corresponding to the retention time (RT) of standard oleanolic acid was recorded and the amount present was calculated from the regression equation obtained from the calibration plot.

\section{RESULTS AND DISCUSSION}

\section{Macroscopical characters \\ Exomorphology}

A shrub or small tree; young shoots clothed with stellate hairs. Leaves are bifarious, $7.5-12.5 \times 5-10 \mathrm{~cm}$ oblong, obovate or roundish, cordate, suddenly and shortly acuminate, closely dotted on both surface with stellate hairs, more or less irregularly crenate-serrate; petioles 6-9 $\mathrm{mm}$ long; stipules subulate, $6 \mathrm{~mm}$ long. Flower is $2.5-3.8 \mathrm{~cm}$ long, distinctly bilabiate, in axillary clusters of 2-6 together; pedicels very short, stellately tomentose; bracts small, subulate, hairy. Calyx is tubular, $2 \mathrm{~cm}$ long, somewhat 2-lipped stellately pubescent, curved, laterally compressed, mouth wide; teeth triangular, unequal, Corolla is red at first, fading to lead colour, very unequal closely reflexed on the calyx. Separate but with the claws closely hooked together. Androecium is staminal column fused with gynophores, much exserted, suddenly deflexed; anthers 10 , in a ring round the ovary. Ovary is conical, $3.8 \mathrm{~cm}$ long; style as long as ovary, deflexed. Fruit is follicle 5, beaked, $5-6.3 \mathrm{~cm}$ long, linear, twisted together into the form of a screw, stellately tomentose. Seeds are numerous, angular; testa loose wrinkled (Figure 2).

Root is a tap root with wiry rootlets, cylindrical, $5-20 \mathrm{~mm}$ in diameter, rough surface that is exfoliated at places, also shows presence of cracks, longitudinal striations and wrinkles. Fracture of root is short in bark and fibrous in wood. Root does not possess any odour and its taste is bitter (Figure 3).

\section{Microscopical characteristics of transverse section of roots of $\mathrm{H}$. isora}

TS of root shows a cork, phelloderm, secondary phloem and wood region (Figure 4). Cork consists of 10-12 layers of radially arranged tabular 


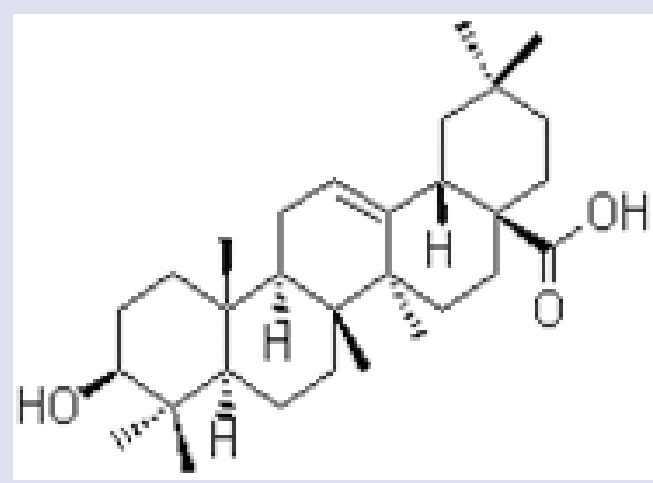

Figure 1: Chemical structure of oleanolic acid

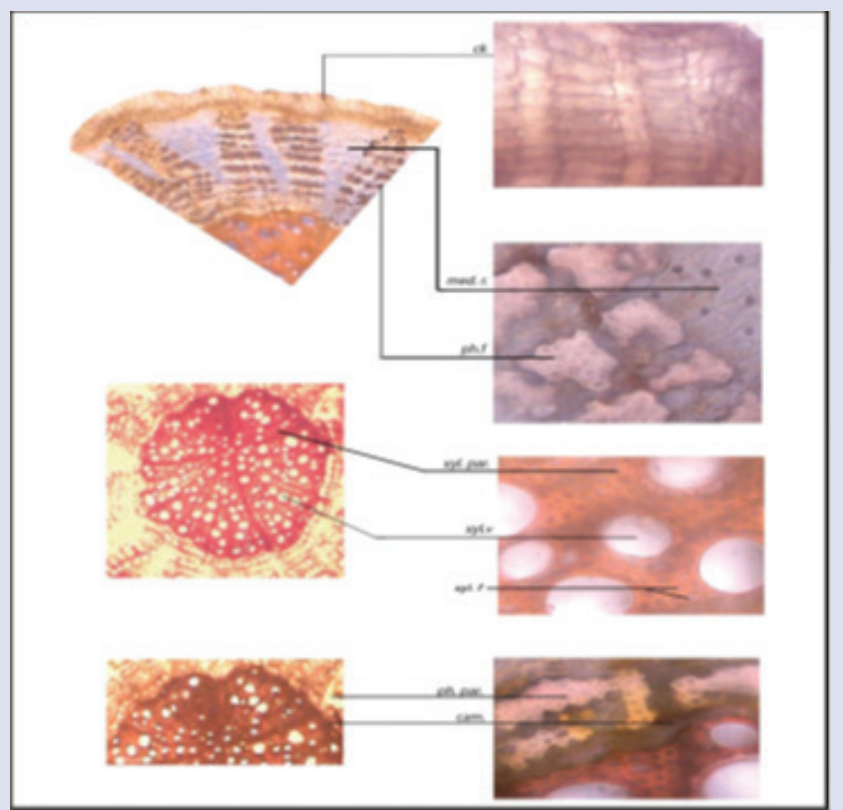

Figure 2: Transverse section of root of $H$. isora cam-cambium, ck-cork, med.r-medullary rays, ph.f- phloem fibre, ph. par.-phloem parenchyma, xyl..par.-xylem parenchyma, xyl.v-xylem vessel

lignified cells. Phellogen is indistinct. Phelloderm consists of 3-5 layered parenchymatous cells containing starch grains, crystals of calcium oxalate rosettes and prisms. Phloem is parenchymatous and traversed with groups of concentrically arranged 25-40 phloem fibres (28-116 $\mu$ ) which are thick walled and lignified. Xylem consists of vessels that are 50-86 $\mu$ in diameter, lignified and in radial rows, xylem fibers that are highly thickened and arranged in tangential bands. Medullary rays are bi-to multiseriate, parenchymatous, narrow in the xylem region and wider in the phloem region. Idioblast containing calcium oxalate rosettes and starch grains are found embedded in in the parenchymatous tissue.

\section{Microscopical powder characteristics (Figure 3)}

The root powder is fine to semi-coarse, fibrous, cream color, odorless and bitter in taste.

Thediagnosticfeaturesofpowderinclude:Lignified, thickwalled polygonal cells of cork in surface view; lignified, bordered pitted xylem vessels up

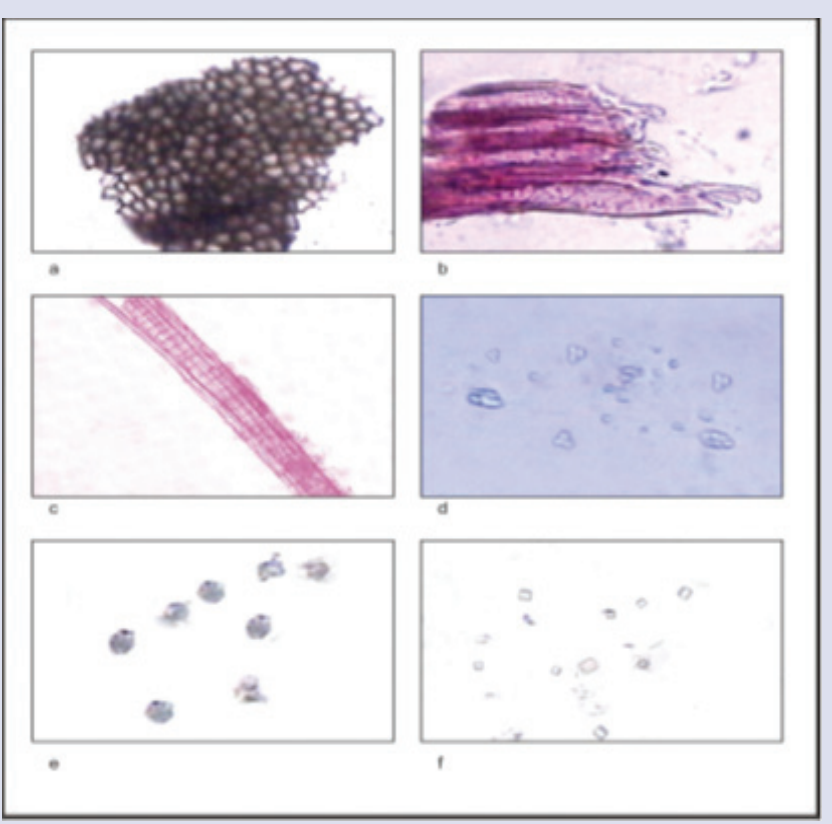

Figure 3: Microscopical powder characteristics of roots of $H$. isora a. cork cells in surface view b. bordered pitted xylem vessels c. phloem fibres

d. starch grains e. rosettes of calcium oxalate crystals

e. prisms of calcium oxalate crystals

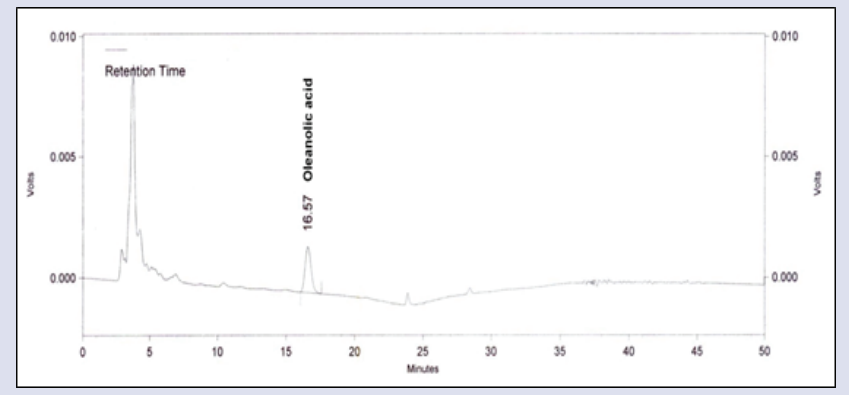

Figure 4: Chromatogram of standard oleanolic acid $(2.0 \mu \mathrm{g} / \mathrm{ml})$ with corresponding retention time RT $=16.57$ at $210 \mathrm{~nm}$ by RP-HPLC method

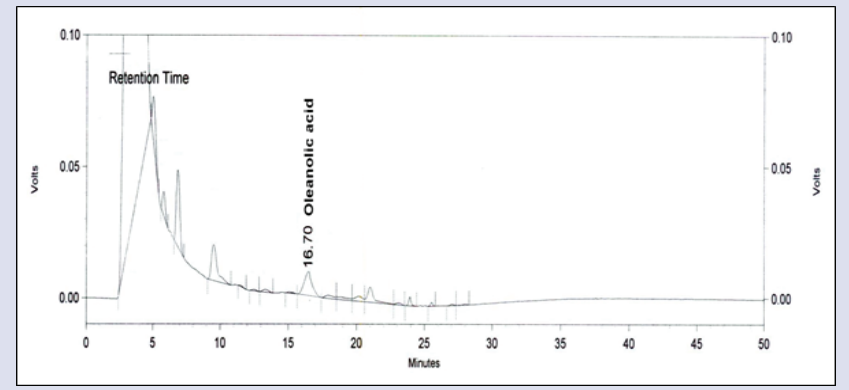

Figure 5: HPLC chromatogram of methanolic sapogenin extract of root of $H$. isora from Gujarat state showing peak of oleanolic acid at RT $16.7 \mathrm{~min}$ 
to $350 \mu$ in length and $50 \mu$ or more in width; Numerous lignified, thick walled, pitted, phloem fibres that are tapering from both ends and found in groups; abundant, simple and compound (2-8 components) starch grains and numerous rosettes and prisms of calcium oxalate.

Physicochemical parameters like ash value, extractive value and loss on drying are mentioned in Table 1.

Phytochemical screening shows presence of saponins, tannins, steroids, flavonoids, mucilage, proteins and sugars (Table 2).

\section{Method optimization}

The HPLC mobile phase was chosen after several trials with acetonitrile, methanol, $0.1 \%$ aqueous orthophosphoric acid and water in various proportions. After investigation, it was found that methanol- $0.1 \%$ aqueous orthophosphoric acid 90:10 $(\% v / v)$ revealed better resolution, high sensitivity and good peak shape. A properly separated oleanolic acid was found at RT 16.57 min retention time (Figure 5).

\section{Method Validation}

The correlation coefficient of calibration plot of peak area versus concentration of standard oleanolic acid was found to be 0.9991 that was indicative of good linearity over a range of $2.0-12.0 \mu \mathrm{g} / \mathrm{ml}$ of oleanolic acid (Table 3 ). The linear regression equation is $\mathrm{y}=28463 \mathrm{x}+1420.4$ where $\mathrm{y}$ is response and $\mathrm{x}$ is amount of oleanolic acid.

\section{Accuracy}

The results of recovery of oleanolic acid from root sample of $H$. isora obtained are shown in Table 4 . The \% recovery at three different levels $(50,100$ and $150 \%)$ was found to be $99.16 \pm 1.2583-100.11 \pm 0.6938$ The $\%$ RSD was found to be less than $2 \%$. These results indicate that the proposed method is accurate.

Table 1: Physicochemical parameters of roots of $\boldsymbol{H}$. isora

\begin{tabular}{cc}
\hline Physicochemical parameters & Value $(\% \mathrm{w} / \mathrm{w})$ \\
\hline Total ash & $3.56 \pm 0.15$ \\
Water soluble ash & $2.51 \pm 0.11$ \\
Acid insoluble ash & $0.33 \pm 0.05$ \\
Water soluble extractive value & $5.39 \pm 0.24$ \\
Alcohol soluble extractive value $(\% \mathrm{w} / \mathrm{w})$ & $4.51 \pm 0.11$ \\
Loss on drying & $4.61 \pm 0.03$ \\
\hline
\end{tabular}

Table 2: Phytochemical screening of roots of $\boldsymbol{H}$. isora

\begin{tabular}{cc}
\hline Phytoconstituents & Value \\
\hline Tannins & +++ \\
Saponins & ++ \\
Steroids & + \\
Flavonoids & + \\
Coumarins & - \\
Alkaloids & - \\
Mucilage & + \\
Proteins & ++ \\
Sugars & ++ \\
\hline
\end{tabular}

- : Not detected, + Present in low concentration; ++Present in moderate concentration; +++ Present in higher concentration
Table 3: Linear regression equation data for oleanolic acid by RP-HPLC method

\begin{tabular}{ccc}
$\begin{array}{c}\text { Concentration of } \\
\text { standard oleanolic acid }(\mu \mathrm{g} / \mathrm{ml})\end{array}$ & $\begin{array}{c}\text { Mean peak area } \\
\pm \mathrm{SD}(\mathrm{n}=3)\end{array}$ & \% RSD \\
2.0 & $58709 \pm 668$ & 1.1391 \\
4.0 & $115391 \pm 1376$ & 1.1929 \\
6.0 & $173779 \pm 1671$ & 0.9620 \\
8.0 & $228334 \pm 1906$ & 0.8349 \\
10.0 & $280629 \pm 2967$ & 1.0576 \\
12.0 & $347114 \pm 3459$ & 0.9966 \\
\hline
\end{tabular}

Table 4: Results from determination of recovery of oleanolic acid from root powder of $\boldsymbol{H}$. isora

\begin{tabular}{cccccc}
\hline $\begin{array}{c}\text { Level } \\
\text { of sample } \\
\text { taken } \\
(\mathrm{mg})\end{array}$ & $\begin{array}{c}\text { Amount } \\
\text { of } \\
\text { standard } \\
\text { spiked } \\
(\mathrm{mg})\end{array}$ & $\begin{array}{c}\text { Total } \\
\text { amount } \\
\text { recovered } \\
(\mathrm{mg})\end{array}$ & $\begin{array}{c}\text { \%Recovery } \\
\pm \mathrm{SD}\end{array}$ & $\begin{array}{c}\% \text { RSD } \\
(\mathrm{n}=3)\end{array}$ \\
\hline $50 \%$ & 2.0 & 1.0 & 2.99 & $99.33 \pm$ & 1.5378 \\
$100 \%$ & 2.0 & 2.0 & 3.98 & $99.16 \pm$ & 1.2689 \\
& & & & 1.2583 & \\
$150 \%$ & 2.0 & 3.0 & 5.00 & $100.11 \pm$ & 0.6931 \\
& & & & 0.6938 & \\
\hline
\end{tabular}

Table 5: Results from determination of intra and interday precision for oleanolic acid

\begin{tabular}{|c|c|c|c|c|}
\hline \multirow{2}{*}{$\begin{array}{l}\text { Concentration } \\
\text { Of standard } \\
\text { oleanolic acid } \\
(\mu \mathrm{g} / \mathrm{ml})\end{array}$} & \multicolumn{2}{|c|}{ Intraday precision $(n=3)$} & \multicolumn{2}{|c|}{ Interday precision $(\mathrm{n}=3)$} \\
\hline & $\begin{array}{c}\text { Peak area } \\
(\text { Mean } \pm \text { SD) }\end{array}$ & $\%$ RSD & $\begin{array}{c}\text { Peak area } \\
(\text { Mean } \pm \text { SD) }\end{array}$ & $\%$ RSD \\
\hline 4.0 & $115391 \pm 1376$ & 1.1929 & $115591 \pm 1631$ & 1.4154 \\
\hline 6.0 & $173779 \pm 1671$ & 0.9620 & $174112 \pm 2182$ & 1.2533 \\
\hline 8.0 & $228334 \pm 1906$ & 0.8341 & $228067 \pm 2344$ & 1.0279 \\
\hline
\end{tabular}

Table 6: Summary of validation parameters for estimation of oleanolic acid from the roots of $H$. isora by HPLC method

\begin{tabular}{cc}
\hline Parameters & Results \\
\hline Correlation coefficient $(\mathrm{R} 2)$ & 0.9991 \\
Linearity and range $(\mu \mathrm{g} / \mathrm{ml})$ & $2.0-12.0$ \\
Regression equation & $\mathrm{y}=28463 \mathrm{x}+1420.4$ \\
Precision $(\% \mathrm{RSD})$ & \\
Repeatability of area & 0.4075 \\
Repeatability of retention time & 0.2408 \\
Intraday & $0.8341-1.1929$ \\
Interday & $1.0279-1.4154$ \\
\% Recovery & $99.16 \pm 1.2583-$ \\
Limit of detection $(\mu \mathrm{g} / \mathrm{ml})$ & $100.11 \pm 0.6938$ \\
Limit of quantification $(\mu \mathrm{g} / \mathrm{ml})$ & 0.03 \\
Robustness & 0.1 \\
\hline
\end{tabular}




\section{Precision}

The $\%$ RSD value of instrumental precision was found to be 0.4075 . The low value of RSD indicates that the proposed method is precise.

\section{Intermediate precision (Reproducibility)}

The results of intraday precision and inter day precision expressed as $\%$ RSD are shown in Table 5. The \% RSD of intraday and interday precision was in the range of 0.8341-1.1929 and 1.0279-1.4154 respectively. The results show that the method is reproducible.

\section{Limit of Detection and Limit of Quantification}

The limit of detection (LOD) and limit of quantification (LOQ) was found to be $0.03 \mu \mathrm{g} / \mathrm{ml}$ and $0.1 \mu \mathrm{g} / \mathrm{ml}$ respectively. The low value of LOD and LOQ revealed that the given method was found to be sensitive.

\section{Robustness}

The results of robustness for each parameter were expressed in terms of $\%$ RSD. The \%RSD for each parameter was found to be less than $2 \%$ indicated that the standard oleanolic acid was not adversely affected by these changes. Hence the given method was found to be robust.

Overall results of method validation parameter were given in Table 6.

\section{Quantification of oleanolic acid in sapogenins of roots of $\mathrm{H}$. isora}

The content of saponins and sapogenins found in the roots of $H$. isora $0.425 \% \mathrm{w} / \mathrm{w}$ and $0.13 \% \mathrm{w} / \mathrm{w}$ respectively. The peak of separated oleanolic acid from sapogenins was found at retention time $16.70 \mathrm{~min}$ in HPLC chromatogram of methanolic sapogenin extract of root (Figure 5). The amount of oleanolic acid in roots of $H$. isora obtained from Gujarat India is $0.076 \% \mathrm{w} / \mathrm{w}$.

\section{CONCLUSION}

The pharmacognostical study of the roots of $H$. isora will be useful for proper identification of the drug. The proposed HPLC method is accurate, reliable and precise. It can be used as routine quality control method for estimation of oleanolic acid sfrom $H$. isora.

\section{ACKNOWLEDGEMENT}

Authors are thankful to Dr. Minoo Parabia, Ex. Dean and Head of the Bioscience Department, The Veer Narmad South Gujarat University, Surat for identification and authentication of plant.

\section{CONFLICT OF INTEREST}

The authors have no conflict of interest.

\section{ABBREVIATION USED}

HPLC: High Performance liquid chromatography; LOD: Limit of detection; LOQ: Limit of quantificationn.

\section{REFERENCES}

1. Kirtikar KR, Basu B. Indian Medicinal Plants. L.M. Basu, Allahabad; Reprinted
Edition, Vol.1, 1933. p. 371-2.

2. Anonymous. The Wealth of India (Raw materials). Council of Scientific and Industrial Research, New Delhi; Vol.V, 1959.p.27-9.

3. Watt G. A Dictionary of the Economic Products of India. Bishen Singh Mahendrapal Singh, Dehradun; Second reprint, Vol. IV, 1972. p.212.

4. Chopra RN, Nayar SL, Chopra IC. Glossary of Indian Medicinal Plants. Publication and Information Directorate, CSIR, New Delhi; Reprinted edition, 1986.p. 131.

5. Chopra RN, Chopra IC, Handa KL, Kapur LD. Chopra's Indigenous Drugs of India. U.N. Dhur and Sons Private Limited, Calcutta, 2nd Edition, 1958. p. 340-1.

6. Kumar N. and Singh AK. Plant profile, phytochemistry and pharmacology of Avartani (Helicteres isora Linn.): A review. Asian Pac J Trop Biomed 2014 (1), 22-6. https://doi.org/10.12980/APJTB.4.2014C872; PMid:25183085 PMCid:PMC4025269.

7. Bean MF, Mikhail A, David A, Chang CJ, McLaughlin JL, Cassady JM. Cucurbitacin $\mathrm{B}$ and isocucurbitacin $\mathrm{B}$ : cytotoxic components of $\mathrm{H}$ isora. J Nat Prod 1985;48(3):500. https://doi.org/10.1021/np50039a033; PMid:4031904.

8. Jain A, Sinha P, Desai NS. Estimation of flavonoid, phenol content and antioxidant potential of Indian screw tree (Helicteres isora L.). International J Pharm Sci Res. 2014;5(4):1320-30.

9. Sabale PM, Grampurohit ND, Banerjee SK, Gaikwad DD, Gadhave MV. Recent advances on the phytochemical and pharmacological profile of plant Helicteres isora Linn. International Res J Pharm 2012:3(4):14-7.

10. Bhavsar SK, Foeller M, Gu S, Vir S, Shah MB, Bhutani KK, Santani DD, Lang F Involvement of PI3K/AKT pathway in hypoglycemic effects of saponins from H. isora J Ethnopharmacol 2009;126(3):386. https://doi.org/10.1016/j. jep.2009.09.027; PMid:19781620.

11. Sama V, Reddy DG, Reddy YSR, Sathyavathy D, Reddy BM, Pulla G. Effect of $H$. isora root extract on glucose tolerance in glucose induced hyperglycemic rats. Fitoterapia 2004;75(3):364-7.

12. Chakrabarti R, Vikramadithyan RK, Mullangi R, Sharma VM, Jagadheshan $H$ Rao NY, Sairam P, Rajagopalan R, Antidiabetic and hypolipidemic activity of H. isora in animal models. J Ethanopharmacol 2002;81(3):343. https://doi. org/10.1016/S0378-8741(02)00120-4

13. Bhavsar SK, Singh SG, Jain MR, Santani DD. Effect of saponin fom $H$. isora on lipid and glucose metabolism regulating gene expression. J Ethnopharmaco 2009;124(3):426-33. https://doi.org/10.1016/j.jep.2009.05.041; PMid:19505560.

14. Gao DL, Li Q, Li Y, Liu Z, Fan Y, Han Z, Li J, Li K. Antidiabetic potential of oleanolic acid from Ligustrum lucidum Can J Physiol Pharmacol 2007;85:1076-83. https://doi.org/10.1139/Y07-098; PMid:18066109

15. Liu J. Pharmacology of oleanolic acid and ursolic acid. J Ethnopharmacol. 1995;49(2):57-68. https://doi.org/10.1016/0378-8741(95)90032-2.

16. Choi $\mathrm{CY}$, You HJ, Jeong $\mathrm{HG}$. Nitric oxide and tumor necrosis factor-alpha production by oleanolic acid via nuclear factor-kappa B activation in macrophages. Biochem Biophys Res commun 2001;288:49-55. https://doi.org/10.1006/ bbrc.2001.5727 PMid:11594750

17. Dai Y, Hang BQ, Li PZ, Tan LW, Effects of oleanolic acid on immune system and type I allergic reaction. Acta Pharmacol Sin 1989;10:381-4

18. Anonymous. Indian Pharmacopoeia. 4th Edition, Controller of Publications, Govt. of India, Ministry of health and family welfare, Delhi. Vol.2.1996

19. Sharma $V$ and Chaudhary U. Pharmacognostic and Phytochemical Screening of Helicteres isora Linn Roots. Asian J Pharm Clin Res 2016; 9(2):96-101. https:// doi.org/10.22159/ajpcr.2016.v9s2.12178

20. Harde PA, Shah DR, Suhagia BN, Shah MB Development and validation of an HPTLC method for the analysis of oleanolic acid from the roots of Helicteres isora. J Planar Chromatogr 2011;24(6):503-6 https://doi.org/10.1556/JPC.24.2011.6.9

21. Wagner H, Bladt S. Plant Drug Analysis. Berlin: Springer, 1996;64:83. https:// doi.org/10.1007/978-3-642-00574-9

22. International Conference on Harmonization ( $\mathrm{ICH}$ ) of Technical Requirements for Registration of Pharmaceuticals for Human Use: Harmonized Triplicate Guideline on Validation of Analytical Procedures: Methodology, Recommended for Adoption at Step 4 of the ICH Process on November 1996 by the ICH Steering Committee, IFPMA, Switzerland 